\title{
SOKRATES CAFÉ JAKO SPOSÓB KSZTAŁTOWANIA POSTAWY FILOZOFICZNEJ NAUCZYCIELA FILOZOFII I ETYKI
}

\begin{abstract}
Streszczenie: Nauczanie filozofii i etyki w warunkach zmieniającej się polskiej szkoły jest wyzwaniem, które wymaga od nauczyciela szczególnego zaangażowania w pielęgnowanie własnej postawy filozoficznej. Autorka dostrzega sprzeczności w zdefiniowaniu roli nauczyciela zarówno w świetle wymaganych kompetencji edukacyjnych, jak i ogólniejszej kwestii pielęgnowania „postawy filozoficznej”. Inspiracją dla rozwiązania trudności staje się zjawisko Sokrates Café - otwartych spotkań dyskusyjnych. Dla autorki stanowią one sposób na wzbogacenie praktyki edukacyjnej oraz samorozwój nauczyciela filozofii i etyki.
\end{abstract}

Słowa kluczowe: edukacja filozofii i etyki, kompetencje nauczyciela, postawa filozoficzna, Sokrates Café

Strukturę pracy wyznaczają pytania, które zadaję, analizując własną praktykę uczenia filozofii i etyki w szkole. Pytania te często pozostają bez odpowiedzi, przechodzą raczej $\mathrm{w}$ kolejne pytania, ujawniając tym samym kontekst, w którym zostały sformułowane. Pytania formułowane są z perspektywy nauczyciela, często przenikają się nawzajem. Jak uczyć filozofii i etyki dzisiaj? Po co uczyć? Co to znaczy być nauczycielem filozofii i etyki? Czym jest filozofia? Jakich kompetencji wymaga nauczanie filozofii? Czy wreszcie, jak pielęgnować w sobie postawę filozoficzną? Jakie znaczenie ma postawa nauczyciela dla praktyki dydaktycznej? Zdaję sobie sprawę, że na tak postawione pytania odpowiedzieć wyczerpująco i jednoznacznie nie sposób. Niemniej jednak stanowią one stały element refleksji nauczyciela. To w kontekście tych pytań definiujemy naszą praktykę i właściwie jesteśmy zmuszeni odpowiadać na nie ciągle na nowo. Refleksja wokół tych pytań-problemów stanowi pierwszą część artykułu. Dalej analizuję fenomen Sokrates Café jako współczesny sposób na pielęgnowanie postawy filozoficznej.

Jakich kompetencji wymaga nauczanie filozofii? To pytanie, które zadaję z perspektywy nauczyciela rzuconego w rzeczywistość szkoły, który czuje, że mu czegoś brakuje. Doświadczenie zarówno braku, jak i poszukiwania rozwiązań, inspiracji dla praktyki edukacyjnej, wyznaczają punkt wyjścia podjętych tutaj rozważań.

Studia na kierunku filozoficznym ze specjalnością nauczycielską dały mi przede wszystkim pewne wyobrażenie o historii filozofii jako całości, z jej poszczególnymi nurtami i ich specyfiką, nazwiskami co ważniejszych przedstawicieli owych nurtów czy szkól, oraz kilkorgiem „wolnych ptaków”, których historia filozofii pokochała, mimo że nie doczekali się naśladowców. Ćwiczono nas, studentów, przede wszystkim w zakresie analizy tekstu 
filozoficznego (co w praktyce polegało na uzgadnianiu z prowadzącym zajęcia znaczenia czytanych fragmentów) oraz dyskusji. Dzisiaj, z perspektywy nauczyciela, muszę przyznać, że akademickie przygotowanie do dyskusji, nie na wiele przydaje się w szkole. Uczniów (przynajmniej tych, z którymi się spotkałam) nie interesuje pierwsze, drugie czy siódme odczytanie Platona, a już na pewno nikt nie będzie się ze mną na ten temat poważnie spierał.

Etyka i filozofia to przedmioty nowe we współczesnej polskiej szkole, co ma szereg konsekwencji dla praktyki nauczyciela. Jest to trudny czas przecierania szlaków, wypracowywania programów i rozwiązań dydaktycznych, jak również zmian systemowych, które co i raz zmieniają sposoby realizacji tych przedmiotów w szkole ${ }^{1}$. Wciąż niewielka, a na pewno niewystarczająca oferta wydawnicza dotycząca pomocy dydaktycznych dostosowanych do specyfiki tych przedmiotów oraz różnych poziomów nauczania (brak ćwiczeń, brak dobrych podręczników, pomocy wizualnych, programów nauczania itd.) obciąża nauczyciela koniecznością przygotowywania wszystkich materiałów potrzebnych do realizacji zajęć ${ }^{2}$.

Kolejnym wyzwaniem, przed jakim staje nauczyciel etyki czy filozofii, są to kwestie organizacyjne. Etyka i filozofia na wszystkich poziomach nauczania są przedmiotami nieobowiązkowymi ${ }^{3}$. Etyka jest realizowana na wniosek rodziców lub w przypadku uczniów pełnoletnich - samych zainteresowanych. Jako przedmiot nieobowiązkowy właśnie, realizowana jest w grupach międzyklasowych, często nie jest nawet ujęta w tak zwanej „siatce godzin” i z konieczności odbywa się na ostatnich $(9,10)$ godzinach lekcyjnych, po godzinach przedmiotów obowiązkowych, których ilość po ostatniej reformie programowej jest doprawdy przytłaczająca. Jak w tych warunkach organizacyjnych zachęcić uczniów do udziału w zajęciach?

W tym miejscu odkładam jednak problematykę warunków zewnętrznych organizujących szkolną dydaktykę na rzecz rozważań nad procesem nauczania filozofii i etyki. Powyższe zagadnienia (np. Czy przedmiot jest dla ucznia obowiązkowy, czy nie? Na której godzinie lekcyjnej będzie realizowany?) są oczywiście ważne, ponieważ wpływają na jakość lekcji, ale niedobrze jest, gdy pochłaniają zbyt wiele energii nauczyciela, która powinna być skierowana na to, co od nas samych zależy. Dlatego w dalszej części tekstu skupię się na samym procesie uczenia. Zresztą historia filozofii pokazuje, że filozoficzne pytania o sens zawsze są stawiane nie w porę, na przekór społecznym oczekiwaniom i utrwalonej organizacji życia społecznego. Wystarczy przywołać postać Sokratesa, który filozofując, naraził się wszystkim ważnym decydentom swojego polis i był do tego stopnia niewygodny, że został skazany na śmierci. Nie powinno zatem dziwić, że podejmując się kształcenia filozoficznego młodzieży, napotykamy na opór.

1 Np. ostatnie rozporządzenie z 25 marca 2014 r. zmieniające rozporządzenie w sprawie warunków i sposobu organizowania nauki religii w publicznych przedszkolach i szkołach, szczegółowe informacje z Dz. U. z 2014 r., poz. 478.

2 Sytuacja ta ma swoje złe i dobre strony. Zobowiązuje nauczyciela do dużego nakładu dodatkowej pracy, poza prowadzeniem i przygotowaniem poszczególnych zajęć, ale również skutkuje dużą różnorodnością treści i sposobów prowadzenia lekcji filozofii, a zwłaszcza etyki.

${ }^{3}$ Zdaję sobie sprawę, że problemy filozoficzne mogą występować również na innych przedmiotach, jak np. język polski. Powołuję się tutaj na rozróżnienie Martensa na zainteresowanie filozoficzne i zainteresowanie filozofią (Martens, Schnädelbach 1995, s. 42-48). 
Uczenie filozofii to wyzwanie szczególne. Jak mówić o abstrakcyjnych problemach filozoficznych w szkole? To codzienna gimnastyka umysłu nauczyciela w poszukiwaniu kolejnych przykładów obrazujących ogólne idee filozoficzne, sztuka ujmowania tych idei w schematy, ilustracje, gry, komiksy, nawet bajki w młodszych klasach, zdolne poprzez wizualizację zainteresować i utrzymać uwagę uczniów. Niektórzy z filozofów wątpią, czy to jest w ogóle możliwe ${ }^{4}$.

Prawdziwą sztuką jest umiejętność prowadzenia dyskusji filozoficznej. Jak to dobrze robić? Jak przeobrazić klasę, wraz z nauczycielem, we wspólnotę dociekającą (Lipman i in. 2008)? Czasami to się udaje, ale nie zawsze. I te doświadczenia, gdy mimo wielu starań z naszej strony, dyskusja nie wychodzi, to również część codziennego doświadczenia, z którym nauczyciel filozofii musi jakoś sobie radzić.

Czym jest dyskusja filozoficzna? „W swym najbardziej podstawowym znaczeniu termin ten odnosi się do procesu rozumowania, którego celem jest dotarcie do prawdy lub wiedzy na dowolny temat." (Blackburn 2004, s. 86) W oparciu o powyżej przytoczone, źródłowe znaczenie terminu dialektyka, można wnosić, że dyskusja filozoficzna to coś, co się tylko czasami na lekcji przydarza. Podstawą jest wspólny cel, ze względu na który podejmujemy dyskusję, a także zaangażowanie $\mathrm{w}$ dociekanie do prawdy. Poglądy powinny być formułowane w sposób bezinteresowny (ze względu na prawdę, a nie własne interesy), uczciwie i z gotowością do wycofania się z raz przyjętych twierdzeń, jeżeli w toku rozumowania okażą się niesłuszne lub nie dość dobrze uargumentowane. Jest to pewien ideał, który niewiele ma wspólnego z rzeczywistością szkolną. Lekcja filozofii, z samego faktu, że toczy się w ramach instytucji, jaką jest szkoła, przyjmuje pewne ramy zewnętrzne, które wyraźnie wpływają na jej kształt oraz warunkują możliwości tego, co się może bądź nie może wydarzyć. Ramy instytucjonalne to przede wszystkim: jednostka czasowa, w ramach której toczy się lekcja, dystans między uczniem a nauczycielem (nauczyciel jako ten, który wie, i uczeń, który nie wie i w związku z tym jest w pozycji podporządkowanej względem nauczyciela), konieczność realizowania programu. Wszystkie wyżej wymienione czynniki ograniczają swobodę dyskusji. Gdy nauczyciel zadaje pytanie, uczeń czuje się odpytywany, za swój obowiązek bierze odgadywanie tego, co nauczyciel chciałby w odpowiedzi usłyszeć. Również nauczyciel, w tej tradycją uświęconej relacji, zobowiązany jest do tego, aby wiedzieć - i czy chce, czy nie - w jakiś sposób musi dźwigać to brzemię. Nie każdy i nie zawsze przyznaje się, że nie wie, a tylko wtedy dyskusja, jako wspólne poszukiwanie prawdy, staje się możliwa (Folkierska 1995; Rutkowiak 1992).

Te mechanizmy działania instytucji szkolnej tkwią w nas bardzo głęboko, utrwalone wieloletnim treningiem w roli ucznia, a później i nauczyciela. Najczęściej poddajemy się im nieświadomie. Czasem są to drobne rzeczy, pozornie nieistotne i niezamierzone. Na przykład, kiedy w czasie dyskusji rozbrzmiewa dzwonek kończący lekcję, to kierowani odruchem przerywamy i od tej pory myślimy już tylko o tym, że za chwilę jest koniec, a co gorliwsi wstają i zaczynają pakować swoje rzeczy. Dzwonek to strzał armatni, który ustawia na pozycje startowe i każe biec. Jeżeli nauczyciel nie podsumuje dyskusji przed

\footnotetext{
4 Czy filozofii można nauczać? Czy nauczanie filozofii jest w ogóle możliwe? Po co studiować filozofię? Elitarność filozofii? Czy nauczanie filozofii jest potrzebne? - same tytuły publikacji dotyczących edukacji filozoficznej zdradzają tę niepewność, na co zwrócił uwagę Wojciech Ostrowski w pracy O kształceniu filozoficznym oraz dydaktyce filozoficznej (Ostrowski 2009, s. 249-267).
} 
dzwonkiem, to już przepadło. Po dzwonku już nic się nie da zrobić. Z kolei ja sama łapię się na tym, że zagaduję każdą możliwą ciszę na lekcji. A przecież, żeby pomyśleć naprawdę, trzeba mieć czas ${ }^{5}$, trzeba pozwolić na ciszę. Myślenie ze swej natury dotyczy tego, czego nie wiem, a nie pytań pozornych, na które mamy już z góry przemyślaną odpowiedź (Heidegger 200o). Wiem o tym, a jednak często zachowuję się tak, jakby wkradająca się do rozmowy cisza była wrogiem i trzeba ją było natychmiast rozbroić poprzez: zmianę tematu, dodatkowe pytania ( o tyle pomocowe, o ile przeszkadzające wobec pytania pierwszego, którego być może wciąż wybrzmiewający sens zagłuszyły), moje próby podpowiedzi-odpowiedzi. Czasem też przekierowuję pytanie w stronę innego ucznia, który może szybciej coś „rzuci”, ale przecież niekoniecznie pomyśli.

Wreszcie chciałabym poruszyć kwestię bardziej osobistą, ale mającą również niezmierne znaczenie dla jakości dydaktyki: jak utrzymać żywe zaangażowanie w pracę z uczniami, fascynację uczeniem filozofii, gdy w życiu zawodowym stale napotykamy na opór? Nauczyciel filozofii, bardziej niż nauczyciele innych przedmiotów, narażony jest na lekceważenie w stosunku do własnej pracy, przedmiotu zainteresowań, czy bardziej ogólnie, sensowności jego obecności w szkole, a nauczanego przedmiotu w systemie nauczania.

Podejmując refleksję nad możliwymi przyczynami niepowodzeń pewnych podejmowanych przeze mnie działań dydaktycznych, a także nad doświadczanym brakiem kwalifikacji we mnie jako nauczycielu filozofii, dochodzę do wniosku, że istota problemu nie polega na braku kompetencji, tak jak to założyłam na wstępie. Zgadzam się z analizami Delli Fish, że myślenie w kategoriach kompetencji „polega na «uproszczeniu problematyczności» procesu nauczania (nauczanie zostaje ograniczone do opanowania kilku sprawności i strategii), przypisaniu prostego, zrozumiałego znaczenia autentycznej złożoności (tak jakby poszukiwanie sprawności i strategii było sprawą prostą, dobrze znaną, co do której wszyscy się zgadzają), prezentowaniu wiedzy jak o absolutu, gdy tymczasem większość występujących w niej koncepcji ma charakter hipotetyczny, zdepolityzowaniu tego, co samo w sobie jest esencjonalnie polityczne, pomijaniu moralnego aspektu czynności nauczania, uniwersalizowaniu tego, co ma wymiar jednostkowy (nie ma takich strategii i umiejętności, które są skuteczne w każdej sytuacji), pretendowaniu do obiektywnego ujmowania czegoś, co jest kontestowane wewnętrznie (ocenianie każdego studenta w ten sam sposób, w odniesieniu do tego samego standardu, prowadzi do wykorzenienia subiektywnego wymiaru edukacji)" (Gołębniak 1998, s. 46-48).

W badaniach pedagogicznych dotyczących kondycji współczesnego nauczyciela spotykam się z metaforą programowego (nie)przygotowania. W tekście Pytanie o obszary i strategie „domykania” kwalifikacji nauczycielskich Henryka Kwiatkowska i Bogusława Dorota Gołębniak wiążą to (nie)przygotowanie z czasami, w których żyjemy i w których toczy się również rzeczywistość szkolna „uwikłana mocno w dynamiczny proces przemian politycznych i kulturowych ostatniego dwudziestolecia”, co „naznacza realizację zawodu niepewnością zbliżoną do doświadczenia nowicjusza” (Kwiatkowska, Gołębniak 2012, s. 7).

Chciałabym przyjrzeć się tej metaforze (nie)przygotowania w kontekście dydaktyki filozofii. Nauczyciel filozofii również doświadcza niepewności, o której piszą Kwiatkowska i Gołębniak, wynikającej z przeobrażania się współczesnego świata, a w nim współczesnej

${ }^{5}$ Na czas, jako warunek konieczny myślenia wskazał m.in. Pierre Bourdieu w pracy O telewizji. Panowanie dziennikarstwa (Bourdieu 2009). 
szkoły. Zmianom podlegają: programy, nauczane przedmioty (ich zakres, kształt itd.), relacje nauczyciel - uczeń, to, kim jest nauczyciel i jak postrzega swoją rolę w procesie edukacji, kim jest uczeń (znaczenie, jakie przypisuje formalnemu wykształceniu itd.), forma zatrudniania nauczycieli, kształt i znaczenie szkoły w środowisku lokalnym oraz polityce oświatowej... I to tylko niektóre z obszarów reform współczesnej edukacji.

„[...] mówiąc o (nie)przygotowaniu nauczyciela mamy na myśli nie tyle sytuację braku w jego kwalifikacjach, lecz ustawiczny imperatyw ich rozwoju. Ten rozwój polega na wytwarzaniu nowych wartości poznawczych i uczeniu się nowych sprawności działania. Dziś bowiem nie wystarczają techniczne umiejętności badania własnej praktyki. Nauczyciel musi umieć dokonać krytycznego zasobu posiadanej wiedzy i wyuczonych sprawności, a oprócz tego, co jest niełatwe a jest niezwykle ważne - musi być gotowy do rozstania się z tą wiedzą i z tymi sprawnościami, które w odmiennych warunkach działania nie służąc rozumieniu czy wyjaśnianiu nowych zdarzeń, problemów w jego pracy, nie sprzyjają tym samym sprawnemu działaniu" (Kwiatkowska, Gołębniak 2012, s. 8). A zatem, dla autorek, niedomknięcie czy niedopełnienie kwalifikacji nauczyciela związane jest z koniecznością dostosowywania wiedzy i sprawności nauczyciela do zmieniających się warunków jego pracy, tak by zawsze maksymalizować sprawność jego działania.

W przypadku dydaktyki filozofii, (nie)przygotowanie nauczyciela filozofii postrzegam jako szerszy problem, ponieważ ma dodatkowo podstawę w samej filozofii, jest doświadczeniem konstytutywnym, a nie tylko znakiem czasów. Napięcia wewnętrzne filozofii, na które wskazali m.in. Ekkehard Martens i Herbert Schnadelbach w Filozofia. Podstawowe pytania, między ezoteryką i egzoteryką filozofii oraz filozofią jako nauką i filozofią jako oświeceniem $^{6}$, przekładają się na dydaktykę filozofii. Przeciwstawienia te wyznaczają „pewien stan napięcia, który cechuje wszelkie aktualne filozofowanie i wobec którego musi się ono jakoś określić" (Martens, Schnadelbach 1995, s. 52). Problem nie polega na konieczności wyboru jednej z opcji uczenia filozofii: filozofii jako nauki czy filozofii jako oświecenia, lecz na wypracowaniu (albo ciągłym wypracowywaniu, ponieważ napięcia te ze swej natury nie mogą być raz na zawsze przezwyciężone) takiej koncepcji dydaktyki filozofii, w której skrajności te będą się w jakiś sposób uzupełniały. Dodatkowo na programowe (nie)przygotowanie nauczyciela filozofii wpływa sama natura problemów filozoficznych, które ze swej natury są nierozstrzygalne, a próby odpowiedzi na nie zawsze tymczasowe i niewyczerpujące.

Na szczęście Kwiatkowska i Gołębniak widzą w (nie)przygotowaniu potencjał konstruktywny dla kształcenia nauczycieli. „(Nie)przygotowanie nauczyciela nie jest wyrazem braku kompetencji. Kategoria ta opisuje raczej ontyczną naturę jego pracy. w radykalnie zmieniającym się świecie, nie można przygotować nauczyciela na każdą sytuację w miejscu jego pracy. Z tych powodów trzeba uznać, że (nie)przygotowanie ma swoją funkcję

${ }^{6}$ Egzoteryka określa tu zainteresowanie filozofią reprezentowane przez „laików”, czyli od zewnątrz dziedziny, a ezoteryka sposób uprawiania filozofowi właściwy „ekspertom”, od wewnątrz. Filozofia jako nauka orientuje się na przedmiot poznania, a podmiot poznający ujmuje na kształt innych przedmiotów. Celem odniesienia przedmiotowego ma być gwarancja obiektywności („obiektywna prawda i intersubiektywna ważność wiedzy”). Tymczasem filozofia jako oświecenie obejmuje sam podmiot poznający i ma prowadzić do konwersji, czyli takiego odniesienia zdobytej wiedzy do samego siebie, które w sposób istotny zmienia poznającego. Mówiąc językiem Kanta: prowadzi do wyjścia ze stanu dziecięctwa, czyli porzucenia naiwności. 
konstruktywną. Wzmacnia czujność, ostrożność w podejmowaniu decyzji i działaniu. Rehabilituje wątpliwość, afirmuje namysł" (Kwiatkowska, Gołębniak 2012, s. 7). Co więcej, to właśnie pewność w zawodzie nauczyciela jawi się jako niebezpieczna, ponieważ może „unieruchomić refleksję, krytyczne myślenie, poszukiwanie” (Kwiatkowska, Gołębniak 2012, s. 8).

To, co współczesna myśl pedagogiczna nazywa programowym (nie)przygotowaniem nauczyciela, jest stałym elementem postawy filozoficznej, którą najlepiej chyba wyraził Sokrates w znanej formule „wiem, że nic nie wiem”. Wielu mu współczesnych boleśnie odczuło, że posiadana przez nich wiedza, jest tylko wiedzą pozorną, "prawdziwą” tylko w jakimś wąskim kontekście sytuacyjnym. A warunkiem możliwości wszelkiej dyskusji filozoficznej jest „gotowość do rozstania się z dotychczasową wiedzą”.

Postawa filozoficzna ${ }^{7}$, jak to się przyjęło określać, polega na umiejętności dziwienia się, na ciekawości właściwej dzieciom i filozofom właśnie, która wyraża się w ciągłym pytaniu o otaczający nas świat i o nas samych (Kim jestem? Co znaczę? Co mogę? Co powinienem?). Sztuka problematyzowania rzeczywistości (Pobojewska 2011, 2012), jeżeli nie jest rozwijana, najczęściej zanika wraz z dziecięctwem. Ulegamy prymatowi działania nad myśleniem ${ }^{8}$. Chcąc działać skutecznie w życiu codziennym, przystajemy na uproszczoną wizję świata, w którym rzecz jest tym, na co wygląda. Filozofia rozbija tę skorupę oczywistości, komplikuje nasz świat codzienny poprzez prymat dociekania prawdy nad skutecznością działania. W dociekaniu filozoficznym rzeczy jawią się wielowymiarowo, a pytanie o skuteczność działania uzupełniane jest pytaniem o dobro.

Samokształcenie nauczyciela filozofii i etyki powinno, w mojej ocenie, dotyczyć przede wszystkim pielęgnowania postawy filozoficznej. Przypatrując się praktykom duchowym filozofów starożytnych, można dostrzec, że pielęgnowanie postawy filozoficznej jest pewnym sposobem życia. „Akt filozoficzny nie jest umieszczony jedynie w porządku poznania, lecz również w porządku «samego siebie» i w porządku istnienia; to akt postępu, który sprawia, że bardziej jesteśmy, który czyni nas lepszymi. Jest to konwersja powodująca przewrót w całym życiu, zmieniająca byt tego, który jej dokona" (Hadot 2003, s. 13). Ćwiczenia duchowe starożytnych są zarazem ćwiczeniem myślenia, jak i ćwiczeniem moralnym.

Pierre Hadot wyróżnia cztery podstawowe cele ćwiczeń duchowych: 1. nauczyć się żyć, 2. nauczyć się rozmawiać, 3. nauczyć się umierać i 4. nauczyć się czytać. Aby konwersja potocznego myślenia w myślenie filozoficzne mogła się dokonać, konieczne jest zapanowanie nad namiętnościami. „Przechodzi się od «ludzkiego» widzenia rzeczywistości - takiego, w którym wartości zależą od namiętności - do «naturalnego» widzenia rzeczy, które stawia każde zdarzenie w wymiarze natury powszechnej” (Hadot 2003, s. 15). Aby to osiągnąć, filozofowie starożytni polecają ćwiczyć zwłaszcza uwagę, medytację, umieranie i obojętność na rzeczy obojętne.

7 Postawa na gruncie nauk społecznych to stanowisko, sposób postępowania, który organizuje całość myślenia, określa stosunek do otaczającej rzeczywistości, tendencje do pewnego rodzaju zachowań, nastawienie, a także warunkuje siłę i charakter emocji, które towarzyszom doświadczeniom czy podejmowanym działaniom i (Janus 2011, s. 212). a zatem tak rozumiana postawa jest „sposobem życia”, która sięga tym razem do określeń filozofii starożytnej.

8 Filozofia współczesna nazywa to rozumem instrumentalnym, zob. m.in. Habermas 2002. 
Ćwiczenie uwagi, czyli skupienie na chwili obecnej, pozwala rozpoznać siebie we własnej aktualności. To, kim jestem, wyznacza zakres możliwości działania i pozwala uwolnić się od namiętności, według starożytnych najczęściej związanych z przeszłością lub przyszłością, które ode mnie nie zależą. Zgubne jest pragnienie rzeczy od nas niezależnych, ponieważ czyni nasze życie niespełnionym, nieszczęśliwym i odsuwa nasze myślenie od tego, co istotne. Przede wszystkim jednak uwolnienie od namiętności jest warunkiem autonomii moralnej jednostki. Filozofia starożytna przedstawia wolność indywidualną jako zadanie, w którym trzeba się ćwiczyć.

Medytacja w filozofii stoickiej również miała chronić duszę przed niepotrzebnym cierpieniem poprzez przygotowywanie jej na niepożądane, przyszłe zdarzenia. Zalecane formy medytacji to dialog z samym sobą, dialog z innymi i pisanie. Pomocna dla medytacji jest lektura tekstów filozoficznych, słuchanie wykładów czy samodzielne badanie problemów filozoficznych. Kształtujemy w ten sposób nawyki definiowania przedmiotów, zdarzeń i postrzegania ich w szerszej perspektywie. Tymczasem w filozofii epikurejskiej medytacja polegała na kontemplowaniu przyjemności, nieważne, czy przeszłych, przyszłych, czy aktualnych. Celem było odprężenie duszy i zmiana optyki widzenia. Przykładem jest kontemplacja faktu istnienia, który stanowi niezrównaną wartość życia, a który dla ludzi nieświadomych (niepotrafiących sobie wyobrazić, że przecież mogłoby być inaczej) w życiu codziennym nie przedstawia żadnej wartości.

Praktykowano również obojętność na rzeczy obojętne, panowanie nad sobą czy spełnianie obowiązków życia społecznego. W filozofii starożytnej ważny jest nie tylko rozwój moralny, ale poznanie jako takie („kontemplacja świata fizycznego i wyobrażanie nieskończoności" (Hadot 2003, s. 27)), dzięki któremu przekraczamy perspektywę jednostkową, a widząc wieloaspektowo, możemy żyć pełniej, bardziej świadomie i zapanować nad strachem.

Hadot przedstawia dialog sokratyczny jako podstawę każdeg o ćwiczenia duchowego. "Z tego punktu widzenia każde ćwiczenie ma charakter dialogu o tyle, o ile jest ćwiczeniem autentycznej obecności, własnej i cudzej" (Hadot 2003, s. 37).

Prawdziwym wyzwaniem filozoficznym jest zalecenie, by „odsunąć myśl od wszystkiego, co śmiertelne i cielesne i zwrócić się ku aktywności intelektu.” (Hadot 2003, s. 52). „Odsunąć myśl od wszystkiego, co śmiertelne i cielesne” t o wyzwolić się z ograniczeń własnej jednostkowości, z niewoli namiętności, troski o dobra materialne i życiową wygodę. " "Ćwiczenie się w śmierci» łączy się tu zatem z kontemplacją całości i wyniesieniem myśli, przechodząc od subiektywizmu jednostkowego i emocjonalnego do obiektywizmu perspektywy uniwersalnej, czyli do ćwiczenia myśli czystej. [...] Cała spekulatywna i refleksyjna praca filozofa staje się w ten sposób ćwiczeniem duchowym o tyle, o ile wynosząc myśl do wymiaru Całości, uwalnia ją ze złudzeń jednostkowości” (Hadot 2003, s. 47).

Uważam, że takie całościowe myślenie o doskonaleniu nauczyciela filozofii (wzorem filozofów starożytnych), pod względem spekulatywnym, moralnym i egzystencjalnym właśnie, otwiera nowe perspektywy myślenia o jego kwalifikacjach bądź ich braku. Postawa filozoficzna wzorem starożytnych to poznanie samego siebie, a następnie dążenie do życia w zgodzie z własnym „ja”. „Utrzymywać się na takich wyżynach było niemożliwością, konwersję musiano sobie wciąż na nowo wywalczać" (Hadot 2003, s. 59). Ulotność filozoficznego postrzegania rzeczywistości stanowi kolejną przesłankę, dlaczego konieczne jest, 
by w swoim życiu ćwiczyć tę perspektywę, która paradoksalnie nie jest dla nas widzeniem naturalnym, chociaż zgodnym z rozumną naturą człowieka.

Doświadczenie Sokrates Café dało mi pewne wyobrażenie, w jaki sposób możliwe jest pielęgnowanie postawy filozoficznej w XXI wieku, ale też dostarczyło takich technik dialogowania z innymi, i dzięki temu ze sobą, że nazwanie źródłowego braku związanego z sytuacją dydaktyczną, od którego zaczęłam te rozważania - stało się w ogóle możliwe.

Sokrates Café znam w wersji, jaką idei dociekań filozoficznych nadał Christopher Phillips w książce Sokrates Café. Świeży smak filozofii i do niej będę się tu odnosić. Książka jest subiektywną relacją ze spotkań, które Phillips odbył pod takim właśnie szyldem i które rozpowszechniły się na inne kraje. W Polsce, w każdym większym mieście (i niektórych mniejszych) regularnie spotyka się grupa sympatyków Sokrates Café. Są to spotkania, na które może przyjść każdy, by wspólnie pofilozofować. To, co łączy wszystkie kluby Sokrates Café, to:

1. Otwartość - przyjść może każdy bez względu na wiek, wykształcenie czy status społeczny. Czasem zdarza się, że osoby, które nigdy o Sokrates Café nie słyszały, a są akurat w kawiarni, w której rozpoczyna się dyskusja, spontanicznie postanawiają się dołączyć.

2. Dyskusja nad problemem filozoficznym - pytanie do dyskusji może postawić każdy, następnie spośród zgłoszonych propozycji obecni wybierają jeden, który organizuje spotkanie.

Sokrates Café różni się od innych, znanych mi wcześniej dyskusji filozoficznych. Zamiast popisów erudycyjnych tu autentycznie poszukuje się odpowiedzi na postawione pytanie. W idei Sokrates Café zawarte jest przekonanie, że filozofia wyrasta z doświadczenia egzystencjalnego i ma zdolność formacyjną. Stąd pytania stawiane są w formie ogólnej, na które poszukiwać odpowiedzi może każdy bez wcześniejszych, specjalistycznych studiów w danej dziedzinie. Różnorodność osób, które biorą udział w rozmowie, pozwala bardzo szybko uchwycić wieloaspektowość pytań, co ośmielam się sądzić, akademickim filozofom zajęłoby znacznie więcej czasu. Czasem aż mnie zdumiewa do jak różnych obszarów sensu odsyłają pojęcia, którymi się posługujemy. Wydaje mi się, że takie poszukiwanie odpowiedzi na pytania filozoficzne jest najbliższe ideałowi, który pozostawił Sokrates. Do tej pory niewiele miałam okazji do tego typu dyskusji. Proszę zwrócić uwagę, że będąc w szkole czy na studiach, dyskutujemy w gronie ludzi w naszym wieku, co istotnie zubaża perspektywę widzenia rzeczy.

3. Bezinteresowność uczestników - nikt tu nie stawia stopni, nie da się w ten sposób awansować, tak jak i o żadnym prestiżu mowy być nie może. Jakby powiedział Sokrates (o ile polubiłby kawę): celem jest troska o własną duszę (Femiak 2010).

4. Uczestnicy Sokrates Café zwracają się do siebie po imieniu. „Chodzi o dyskurs filozoficzny, w którym nikt nie jest guru, a ten, kt o prowadzi dyskusję, więcej uczy się od innych uczestników niż oni od niego" (Phillips 2005, s. 17).

5. Sokrates Café najczęściej odbywa się w kawiarniach, wydaje się, że t o najbardziej naturalne środowisko dla takich dyskusji. Jednak Phillips uważał, że mogą odbywać się wszędzie, jemu samemu zdarzało się prowadzić Sokrates Café w szkołach, więzieniach, kościele...(„Sokrates Café nie musi odbywać się w kawiarni. Może mieć miejsce wszędzie tam, gdzie grupa ludzi - lub «grupa jednoosobowa» - spotyka się, by prowadzić filozoficzne dociekania. Może odbywać się przy stole w jadalni, w kościele, 
w domu kultury, na szczycie góry, w domu spokojnej starości, w hospicjum, klubie seniora, szkole, więzieniu. Wszędzie." (Phillips 2005, s. 19)).

6. Chodzi o poszukiwanie odpowiedzi w sobie samym i próbę wyrażania własnych sądów (a czasem jedynie intuicji poznawczych) bardziej niż o przekonanie dyskutantów do naszych racji. W życiu codziennym, także w szkole, „dyskutowanie” często ogranicza się do poszukiwania takich argumentów, które pozwolą nam przekonać pozostałych. Wiemy z doświadczenia, że często dyskusję „wygrywa” ten, kto miał ostatnie słowo. Podczas Sokrates Café najważniejsze jest dociekanie problemu, a nie przekonywanie. Przypomina dyskusję z Uczty Platona.

7. Punktem wyjścia jest doświadczenie niewiedzy. Zebrani wybierając temat, uznają, że jest to sprawa problematyczna, wymagająca zbadania.

8. Dyskusja nie kończy się żadnym wspólnym wnioskiem czy podsumowaniem, co byłoby zresztą bardzo trudne, biorąc pod uwagę, że dyskusja filozoficzna rodzi zawsze więcej pytań niż odpowiedzi. Korzyść wynoszona ze spotkania ma wyłącznie charakter indywidualny, co odpowiada rozumieniu filozofii jako oświecenia (Martens, Schnadelbach 1995) czy filozofii jako konwersji (Hadot 2003).

Co mi daje Sokrates Café? Co mi daje, jako osobie filozofującej, i co mi daje, jako nauczycielowi filozofii?

1. Przede wszystkim „świeży smak filozofii” - tak jak to zapowiedział Phillips, mogę potwierdzić, że to doświadczenie stało się również i moim udziałem (Phillips tak zapowiada swoją książkę Sokrates Café. Świeży smak filozofii: „ta książka opowiada o moich doświadczeniach zdobywanych w trakcie poszukiwań Sokratesa [...]. Opowiada o tym, jak ponownie odkryłem w sobie zamiłowanie do zadawania coraz to nowych pytań [...].”(Phillips 2005, s. 24)). Możliwość dyskutowania na tematy ważne dla mnie dzisiaj. Pomaga utrzymać wysoką temperaturę uczuć, jakimi darzę filozofię. Odwołując się do etymologii pojęcia, można powiedzieć, że uczestnictwo w spotkaniach Sokrates Café pomaga mi utrzymać i ożywić pierwsze zakochanie w filozofii i filozofowaniu.

O tym, jak ważna jest postawa prywatnego zaangażowania nauczyciela w dziedzinę, którą reprezentuje w szkole, nie muszę chyba nikogo przekonywać. Wszyscy znamy nauczycieli znudzonych tym, czego uczą, zamkniętych w kołowrotkach własnej rutyny. Taki nauczyciel nikogo nie zachęci, ledwo samego siebie udaje mu się przekonać, że warto po raz kolejny mówić to samo. Konieczne jest utrzymywanie „żywego zainteresowania”, zwłaszcza w przypadku nauczyciela filozofii czy etyki, ponieważ są to przedmioty dla uczniów dodatkowe (do wyboru) i w dużej mierze to od nauczyciela zależy, czy uda mu się zachęcić uczniów do udziału w zajęciach. Nie motywuje ich tu żaden dodatkowy czynnik w postaci obowiązkowych egzaminów zewnętrznych. Sokrates Café nie jest na pewno jedynym sposobem pielęgnowania dyskusji filozoficznej, ale jedynym w swoim rodzaju i dość powszechnym (mam tu na myśli sieć klubów Sokrates Café; informacje o spotkaniach w różnych miastach można znaleźć choćby w internecie).

Zaskakujące jest, że wychodząc od problemów nieerudycyjnych, sprowokowanych refleksją nad światem naszego doświadczenia, w którymś momencie dyskusji, nagle uświadamiam sobie, że od przeszło pół godziny prowadzimy niezwykle ożywiony spór o uniwersalia! Jak to się dzieje, że gdybym poruszyła na lekcji problem: „Jak istnieją 
powszechniki?", niechybnie miałby on postać trupa odkopanego na siłę na potrzeby lekcji. W swojej książce Phillips relacjonuje wybrane dyskusje, które prowadził na spotkaniach Sokrates Café, i pełno jest w nich problemów, ale i propozycji rozwiązań, które mają swoich słynnych reprezentantów w dziejach filozofii. To właśnie w tej uniwersalności uwidacznia się doniosłość i znaczenie filozofii. Filozofia nigdy nie staje się historią. Problemy filozoficzne ze swej natury są ostatecznie nierozwiązywalne. Tracą jednak swoją żywotność, jeśli podejmujemy je niczym zdarzenia przeszłe, co więcej, w tej formie „trupiej”. Wtedy na pewno niczyjej myśli nie ożywią, nie porwą.

2. Dzięki uczestnictwu w spotkaniach Sokrates Café odkryłam znaczenie pytań oraz ich przewagę nad odpowiedziami, zwłaszcza w kontekście dydaktyki. Nauczyciel w klasie nie dysponuje gotowymi odpowiedziami (treściami), które może przekazać uczniom", ponieważ żadna odpowiedź na postawiony problem filozoficzny nie jest ostateczna. Co więcej, kiedy próbujemy formułować odpowiedź, najczęściej mnożymy pytania. Lekcje etyki czy filozofii mają sens dopiero, gdy zaczynają się od pytania i to takiego, które zostało przez uczniów uznane za warte dyskusji. Ten moment wspólnego uchwycenia aktualności pytania jest bardzo ważny. Lekcja, tym samym, uzyskuje legitymizację jako wyraz konsensusu osób, które w niej bezpośrednio uczestniczą, a nie tylko dzięki planom zewnętrznych instytucji oświatowych czy samego nauczyciela. W dużej mierze ten moment decyduje o późniejszym zaangażowaniu uczniów w dociekanie, czyli decyduje o „sukcesie dydaktycznym”. Planowanie lekcji z perspektywy konkretnej wiedzy, którą uczeń ma przyswoić, jest $z$ góry skazane na niepowodzenie.

3. Ćwiczenie uważności przez co rozumiem życiową czujność w rozpoznawaniu sytuacji problematycznych, niejednoznacznych. Sokrates Café uczy systematyczności w tym, by te pytania zauważać i zatrzymywać jako rzeczy do przemyślenia. Odwołując się do klasycznej filozofii, nazwę to ćwiczeniem „zmysłu dziwienia się”.

4. Trening w myśleniu. „Zadawanie coraz to nowych i lepszych pytań zapewnia większą osobistą autonomię. Ktoś, kto poszerza horyzonty swojego myślenia i wyobraźni, zaczyna inaczej postrzegać świat i swoje w nim miejsce. Wbrew powszechnemu przekonaniu, im więcej pytań, tym pewniejszy grunt pod nogami. Tym lepsza znajomość siebie" (Phillips 2005, s. 24).

Dyskusje w ramach Sokrates Café są często burzliwe. W tym miejscu przypomina mi się jedna z ostatnich, w jakich brałam udział: ktoś z obecnych zadał pytanie o granice tolerancji, co wszystkich sprowokowało do przywoływania jak najdrastyczniejszych aktów przemocy, tak by jak najdobitniej wykazać, że tolerancja musi mieć swoje granice. Przywoływane argumenty, przykłady zwielokrotnione są dzięki doświadczeniom wielu osób (doświadczenia z krajów, po których podróżowali lub w których mieli okazję mieszkać) - wszystko to składa się na siłę uderzeniową, z jaką problem się uobecnia. Pytanie nie znika wraz z końcem spotkania, często wybrzmiewa we mnie jeszcze przez wiele dni albo powraca w innych dyskusjach, np. na lekcjach.

5. Doświadczenie wspólnoty.

6. Ćwiczenie w umiejętności dyskutowania: formułowania pytań, argumentów i odpowiedzi na kontrargumenty, myślenia w trakcie dyskusji (na gorąco), zabierania

9 To zupełnie odwrotnie niż sugerowałaby podstawa programowa czy sylabus maturalny. 
głosu podczas dyskusji. Podczas lekcji nauczyciel sam sobie udziela głosu, często kosztem czasu na wypowiedzi uczniów, ponieważ zawsze wydaje nam się, że to, co my mamy do powiedzenia, jest najważniejsze. Wypowiadając się podczas Sokrates Café, nie jestem nauczycielem filozofii. Nikt nie „spija prawdy z mych ust”, a raczej z założenia wszystko poddaje się krytyce, co jest świetną odtrutką na zadęcie nauczycielskie (nawyk mówienia głosem sędziego, który odsiewa ziarno od plew). Sokrates Café uważam za bardzo potrzebną okazję do ćwiczenia cierpliwości i pokory, dzięki byciu jednym z dyskutantów, w żaden sposób niewyróżnionym. Szkoła tradycyjnie składa pierwsze skrzypce w ręce nauczyciela, czasem jest to uzasadnione, ale nie wolno się do tego przyzwyczaić!

7. Ćwiczenie pamięci. Spotkania, w których uczestniczę, odbywają się co dwa tygodnie. $\mathrm{W}$ tym czasie moje myśli często wracają do tego, co ostatnio zostało powiedziane. Nie wiem, kiedy to się stało, ale od jakiegoś czasu zapamiętuję przebieg dwugodzinnej dyskusji, co kto powiedział czy pytania, które pozostały bez odpowiedzi. Te rozmowy nadal żyją we mnie. Często w ciągu dnia, podczas rutynowych czynności, te pytania wracają, czuję, że myślę nad nimi dalej, czasem wręcz rozprawiam się z czyimś argumentem. Z relacji Phillipsa wynika, że też tego doświadczał.

8. Dyskutowanie bez odwoływania się do tradycji filozoficznej, konkretnych książek czy filmów. "Metoda sokratyczna polega na odkrywaniu prawd na własną rękę" (Phillips 2005, s. 28; Nelson 1994). Zauważyłam, że podczas zajęć z uczniami mniej skupiam się na przedstawianiu jakiejś historycznej odpowiedzi na dyskutowany problem filozoficzny, a bardziej na samym pytaniu. Coraz częściej nie odczuwam też kaca moralnego, jeśli podczas jakiejś dyskusji nie odwołam się do nazwisk filozofów czy metafor filozoficznych, a skupimy się wyłącznie na aktualnych skojarzeniach uczniów z problemem. Zrozumiałam, jak często na lekcji, nieświadomie za bardziej wartościową uznawałam wypowiedź, która przedstawiała stanowisko któregoś ze znanych mi filozofów niż taką, która była próbą własnego poszukiwania.

9. Dodatkowo każde spotkanie jest przygodą. Zawsze można poznać kogoś nowego, kogo w normalnych warunkach nie miałabym okazji spotkać. Nigdy nie wiadomo też, jakie pytania zostaną postawione, co bywa dość ekscytujące, np. gdy komuś udaje się sformułować bardzo prosto i zwięźle pytanie, które samemu się nosi, nie do końca je sobie uświadamiając, a przeczuwając jedynie w formie ogólnego nastrojenia i tu nagle - eureka!

10. Sokrates Café to „odtrutka” na szkolną rutynę. Dyskusja filozoficzna w warunkach szkolnych ma swoje ograniczenia: czas, konkretne zainteresowania związane z dociekaniem prawdy itd. - nie wszystkie udaje się spełnić. Dyskusja filozoficzna na lekcji czasem się przydarza, kiedy jakieś pytanie wciągnie nas d o tego stopnia, że wszyscy na chwile zapominamy gdzie jesteśmy, że uczniowie mają słuchać, nauczyciel wie i ma zawsze rację, że uwagę należy skupiać na słowach nauczyciela (nie koleżanki), bo to jego tezy będą na sprawdzianie. Kiedy jednak dyskusja filozoficzna już się przydarzy, wówczas dzwonek, który nas z niej wyrywa, jest zawsze zaskoczeniem - to już? To szkoła?

Metoda dociekania filozoficznego w kształcie, jaki nadał jej Phillips, pokazała mi możliwą drogę przejścia od idei dialogu sokratejskiego do praktyki szkolnej. Często nawiązuję 
do filozofii starożytnej w rozmowach z uczniami, ale nie wiedziałam, jak historyczną metodę dialogu uwspółcześnić, jak ją wykorzystać dla naszych potrzeb tu i teraz? Jak pobudzić uczniów do filozofowania? Jak sprowokować ich do samodzielnego myślenia? Sokrates Café traktuję jako pewną interpretację idei dialogu sokratycznego, pewnie nie jedyną możliwą, ale dla mnie bardzo inspirującą. Uczestnictwo w dyskusjach Sokrates Café dostarczyło mi o konkretnych technik, które często modyfikuję na potrzeby danej grupy, ale są dla mnie cennym punktem odniesienia.

\section{Bibliografia}

Blackburn S. (2004). Oksfordzki słownik filozoficzny. Warszawa: Książka i Wiedza.

Bourdieu P. (2009). O telewizji. Panowanie dziennikarstwa, tłum. Sztandar-Sztanderska K., Ziółkowska A., Warszawa: Wydawnictwo Naukowe PWN.

Femiak T., Krasuska-Righesso B., Szymanowski K. (2010). Czy Sokrates polubiłby kawę? „Edukacja filozoficzna”, nr 50, s. 177-190.

Folkierska A. (1995). Kształcaca funkcja pytania. Perspektywa hermeneutyczna. W: Rutkowiak J. (red.). Odmiany myślenia o edukacji. Kraków: Impuls.

Gołębniak B. D. (1998). Zmiany edukacji nauczycieli. Wiedza - Biegłość - Refleksyjność. Toruń - Poznań: Wydawnictwo Edytor.

Habermas J. (2002). Teoria działania komunikacyjnego. T. 2: Przyczynek do krytyki rozumu funkcjonalnego, tłum. Kaniowski A. M., Warszawa: Wydawnictw o Naukowe PWN.

Hadot P. (2003). Filozofia jako ćwiczenie duchowe. Warszawa: Fundacja Aletheia.

Heidegger M. (200o). Co zwie się myśleniem?, tłum. Mizera J., Warszawa; Wrocław: Wydawnictwo Naukowe PWN.

Janus K. (oprac.). (2011). Słownika pedagogiki i psychologii. Zagadnienia. Pojęcia. Terminy. Warszawa: Buchmann.

Kwiatkowska H., Gołębniak B. D. (2012). Wprowadzenie: Pytanie o obszary i strategie „domykania” kwalifikacji nauczycielskich. W: Gołębniak B. D., Kwiatkowska H. (red.). Nauczyciele. Programowe (nie)przygotowanie. Wrocław: Wydawnictwo Naukowe Dolnośląskiej Szkoły Wyższej.

Lipman M., Sharp A. M., Oscanyan F. S. (red.). (2008). Filozofia w szkole. Warszawa: Centralny Ośrodek Doskonalenia Nauczycieli.

Martens E., Schnadelbach H. (1995). O aktualnej sytuacji filozofii. W: Martens E., Schnadelbach H. Filozofia: podstawowe pytania. Warszawa: Wiedza Powszechna.

Nelson L. (1994). Metoda sokratyczna. W: Nelson L. O sztuce filozofowania. Kraków: Wydawnictwo Baran i Suszczyński.

Ostrowski W. (2009.) O kształceniu filozoficznym oraz dydaktyce filozoficznej. W: Pancewicz A., Olejarczyk A., Jaskóła J. (red.). Philosophiae itinera: studia i rozprawy ofiarowane Janinie Gajdzie-Krynickiej. Wrocław: Wydawnictwo Instytutu Filozofii Uniwersytetu Wrocławskiego, Oficyna Wydawnicza ATUT.

Phillips Ch. (2005). Sokrates Café. Świeży smak filozofii. Warszawa: Wydawnictwo Szafa Ewa Korczewska \& Wydawnictwo Punkt Jacek Dziaczkowski.

Pobojewska A. (2012). Początek filozofii: postawy, motywacje, umiejętności. W: Pobojewska A. (red.). Filozofia. Edukacja interaktywna. Metody - Środki - Scenariusze. Warszawa: Stentor. 
Pobojewska A. (2012). Co to znaczy filozofować? „Analiza i egzystencja”, nr 15, s. 99-117. Rutkowiak J. (1992). O dialogu edukacyjnym. Rusztowanie kategorialne. W: Rutkowiak J. (red.). Pytanie, dialog, edukacja: praca zbiorowa. Warszawa: Wydawnictwo Naukowe PWN.

\title{
SOCRATES CAFÉ AS A WAY FOR TEACHERS OF PHILOSOPHY AND ETHICS TO DEVELOP THEIR OWN PHILOSOPHICAL ATTITUDE
}

\begin{abstract}
Teaching philosophy and ethics in Polish education system below academic level is a multidimensional problem. Author notices contradictions that affect the role of a teacher and are related to educational competences and to the more general problem of the 'philosophical attitude'. The solution to some of the mentioned problems is the phenomenon of Socrates Café - discussion groups of philosophy enthusiasts. For the author, Socrates Café is a way to enrich educational practices and improve oneself as a philosophy and ethics teacher.
\end{abstract}

Key words: teaching philosophy and ethics, teacher's competence, philosophical attitude, Socrates Café

Anna Grodek - magister filozofii, doktorantka Uniwersytetu Gdańskiego w zakresie pedagogiki, nauczycielka filozofii i etyki w Ogólnokształcącym Liceum Programów Indywidualnych w Gdańsku. Adres e-mail: ania27@wp.pl 